\title{
Women Friendly Mosque in Banda Aceh: A Study of the Concept of Gender Justice and Gender Planning Perspective
}

\author{
Faradilla Fadlia, ${ }^{1 *}$ Ismar \\ Ramadani, ${ }^{2}$ Siti Nur Zalikha ${ }^{3}$ \\ ${ }^{1}$ Universitas Syiah Kuala, Banda Aceh - \\ Indonesia, ${ }^{2}$ Universitas Almuslim, \\ Bireuen - Indonesia, ${ }^{3}$ Universitas Islam \\ Negeri Ar-Raniry, Banda Aceh - \\ Indonesia
}

Corresponding Author: Faradilla Fadlia, email:faradilla_fadlia@unsyiah.acid Jl. Teuku Nyak Arief No.441 Banda Aceh, NAD 23111

\begin{abstract}
This paper analyzed how several mosques as a public space are not friendly to one gender group. Mosques as public spaces should be accessible to everyone and must accommodate the needs of all gender groups. This study seeks to see how the spatial arrangement that is not friendly to women impacts the comfort of women to worship in the mosque. In addition, this study also tries to analyze mosques in Banda Aceh, which are considered gender-responsive. This study uses qualitative methods with in-depth interviews and uses gender planning theory as an analytical tool. This study found several findings. First, the comfort and discomfort related to the arrangement of space and facilities are experienced by female congregations and male congregations. Second, assumptions that affect spatial planning and facilities have discriminated against one gender group. Third, mosques in Aceh are generally intended for men; this results in the layout of the mosque not accommodating the needs of women.
\end{abstract}

\section{Keywords: mosque; women; gender planning; Aceh; gender responsive}

\begin{abstract}
Abstrak: Artikel ini menganalisis bagaimana sebagian masjid sebagai ruang publik tidak ramah terhadap salah satu kelompok gender. Ruang publik masjid yang diakses oleh semua orang seharusnya dapat mengakomodir kebutuhan semua kelompok gender. Penelitian ini berupaya melihat bagaimana tata ruang yang tidak ramah terhadap gender perempuan ini berdampak pada kenyamanan perempuan untuk beribadah di masjid. Penelitian ini juga berusaha melihat dan menganalisa masjid di Banda Aceh yang dianggap sudah responsif gender. Penelitian ini menggunakan metode kualitatif dengan wawancara mendalam dan menggunakan teori gender planning sebagai alat analisis. Hasil dari penelitian ini menunjukan beberapa hal. Pertama kenyamanan dan ketidaknyamanan terkait tata ruang dan fasilitas tidak hanya dialami oleh jamaah perempuan namun juga jamaah laki-laki. Kedua, asumsi-asumsi yang mempengaruhi tata ruang dan fasilitas telah mendiskriminasi satu kelompok gender. Ketiga, Masjid di Aceh secara umum dimaksudkan untuk laki-laki, hal ini menyebabkan tata ruang masjid tidak mengakomodir kebutuhan perempuan.
\end{abstract}

Kata Kunci: masjid;perempuan; perencanaan berbasis gender; responsif gender 


\section{A. Introduction}

The study of gender, spatial planning and the public space is an interesting issue to research in Aceh because of the masculinities of space. ${ }^{1}$ Women and men have different experiences in accessing public space. This causes public space to be interpreted from different perspectives. From a socio-cultural point of view, the public sphere is defined as a place of interrelation, social interaction, meeting and exchange, where groups with similar interests meet. ${ }^{2}$ Public space is also an "open minded space," that is designed for various uses, including use for something unexpected, and used by citizens from multiple backgrounds that must be tolerated, maybe even those who are interested in certain things or even those who don't want to do anything.' ${ }^{3}$ In addition, public spaces are places that are used by many people and for various activities, they can contribute to the collective identity of society. ${ }^{4}$ From a political point of view, public space is a place where people can participate in public life, and people can voice their aspirations..$^{5}$ At the same time, the architectural group defines public space as a space that is open and accessible to everyone, in contrast to private space, where access is controlled and restricted. ${ }^{6}$ In addition, public space can become a "participatory landscape", which is this part of urban life that reflects culture, beliefs, and values. ${ }^{7}$ Another study shows that public spaces have a role in social integration and cohesion as a city. A positive quality of life is supported by open spaces as necessary for the community.

\footnotetext{
${ }^{1}$ Andrew Gorman-Murray and Peter Hopkins, Masculinities and Place (Oxfordshire: Routledge, Taylor \& Francis Group, 2018).

2Jordi Borja Zaida Muxi, L'espai Públic: Ciutati Ciutadania (Barcelona: Diputació de Barcelona, Àrea de Cooperació, Oficina Tècnica de Cooperació, 2001). 470-75.

${ }^{3}$ Michael Walzer, "Public Space-Pleasures and Costs of Urbanity," Dissent 33, no. 4 (1986):

4Teresa Del Valle, Andamios Para Una Nueva Ciudad: Lecturas Desde La Antropología, vol. 39 (València: Universitat de València, 1997); Karen A Franck and Lynn Paxson, "Women and Urban Public Space," in Public Places and Spaces - Human Behavior and Environment (Springer, 1989), 12146.

${ }^{5}$ Ramón López de Lucio, “El Espacio Público En La Ciudad Europea: Entre La Crisis y Las Iniciativas de Recuperación. Implicaciones Para Latinoamérica Revista de Occidente, 230-231, 2000," Revista de Occidente 230-231 (2000): 105-21.

${ }^{6}$ Grégoire Chelkoff and Jean-Paul Thibaud, "L'espace Public, Modes Sensibles: Le Regard Sur La Ville," in Les Annales de La Recherche Urbaine, 1992, 7-16.

${ }^{7}$ Mark Francis, "Control as a Dimension of Public-Space Quality," in Public Places and Spaces (Springer, 1989), 147-72.
} 
Regarding public space, feminist groups actually see male gender bias in many approaches in urban studies and public space. ${ }^{8}$ It is because architecture and urban planning are male-dominated professions, which causes masculinity to dominate spatial planning as if the interests of men are universal needs. However, women try to participate in urban design and planning to promote gender-wise public spaces. ${ }^{9}$

Regarding gender-biased spatial planning, one of the studies that examine this problem is about special toilets for women and a coffee shop in Banda Aceh, study of the concept of gender justice and gender planning. ${ }^{10}$ This study sees that the presence of women in coffee shops as users of the public space is not accommodated by the coffee shop manager because the coffee shop does not provide women's toilets. Although the number of visitors to female coffee shops increased after the tsunami, the coffee shop was previously dominated by men. Gender equality and planning is used as analytical tools, this study finds; First, women are still not considered part of the coffee shop. Second, if it turns out that women are already part of the coffee shop, there is no awareness of gender needs and the concept of gender planning in the coffee shop by the manager. Third, women want separate toilets from men, even though the need for clean toilets is considered more important in the city of Banda Aceh. Fourth, women are reluctant to complain to the coffee shop manager and ask the coffee shop to provide its toilet, this is due to the cultural factor inherent in the community in Banda Aceh, namely the culture of not being critical of criticism. ${ }^{11}$

\footnotetext{
${ }^{8}$ Dolores Hayden, "What Would a Non-Sexist City Be like? Speculations on Housing, Urban Design, and Human Work," Signs: Journal of Women in Culture and Society 5, no. S3 (1980): S170-87; Clara H Greed, "Planning for Women and Other Disenabled Groups, with Reference to the Provision of Public Toilets in Britain," Environment and Planning A: Economy and Space 28, no. 3 (1996): 57388, https://doi.org/10.1068/a280573; Linda McDowell, Género, Identidad y Lugar: Un Estudio de Las Geografías Feministas, vol. 60 (València: Universitat de València, 2000).

${ }^{9}$ Liz Bondi, "Gender, Class, and Urban Space: Public and Private Space in Contemporary Urban Landscapes," Urban Geography 19, no. 2 (1998): 160-85, https://doi.org/10.2747/02723638.19.2.160; Leonie Sandercock and Ann Forsyth, "A Gender Agenda: New Directions for Planning Theory," Journal of the American Planning Association 58, no. 1 (1992): 49-59, https://doi.org/ 10.1080/01944369208975534; Gerda R Wekerle, “A Woman's Place Is in the City," Antipode 17, no. 2-3 (1985): 145-53.

${ }^{10}$ Faradilla Fadlia, Rizkika Lhena Darwin, and Ismar Ramadani, "Toilet Khusus Perempuan dan Warung Kopi di Banda Aceh (Sebuah Kajian terhadap Konsep Keadilan Gender dan Gender Planning)," Gender Equality: International Journal of Child and Gender Studies 2, no. 1 (2016): 11-22, https://doi.org/10.22373/equality.v2i1.1449.

${ }^{11}$ Fadlia, Darwin, and Ramadani.
} 
Hidayati, lecturer and researcher of the Department of Architecture and Planning, Faculty of Engineering, Gadjah Mada University, conducted research about feminism and urban spatial planning. This study explores the concept of feminism and gender planning in urban and regional planning for industrial indicators whether a region can be considered gender-responsive in spatial planning. This study concludes an area, region, or city that is said to adopt the concept of responsive gender is based on three indicators: no threat, no discrimination, or no marginalization of women in any form, including in terms of access to the use of urban space, which states that men and women have different responsibilities and roles in gender. ${ }^{12}$ This difference is based on the provision of spatial planning divided by gender. In this case, it is explained that the role of men is more to do with physical strength such as fighting, hunting, traveling, and working, while women are synonymous with home and domestic work. Hidayati added that these responsibilities and roles have an impact on spatial design for each gender.

Another research conducted by A. Nurfajrina Amalia Abidin,13 sees that the presence of women in public space such as mosques is a necessity. Therefore, the government should prepare facilities that are responsive to needs, such as separate rooms, changing rooms, special doors so that women do not violate the boundaries of their aurat while in the mosque. In addition, this study examines the representation of women in the Kota Pare-pare mosque. This study indicates that the mosque facilities in the City of Pare-pare are not gender-responsive. Field observation data was used with the category of ablution places: united, separated open, separated, and closed. The findings show that only $5 \%$ of mosques are friendly to women with indicators of setting up separate and closed ablution facilities. This gender-biased facility is due to the fact that male voices are more dominant in the communication process of planning and developing a mosque.

Based on the observations, indirectly, there is a visible difference in the distribution of spatial planning between the sexes of men and women in the mosque. The observation results show that the distribution of prayer space for

\footnotetext{
12 Isti Hidayati, "Feminisme dan Tata Ruang Kota," Research Works and Publications in Urban and Regional Planing Universitas Gadjah Mada, 2015, https://pwk.archiplan.ugm.ac.id/publication/.

${ }^{13}$ Andi Nurfajrina Amalia, "Memahami Karateristik Perempuan di Masjid," OSF Preprint, 2020, https://doi.org/10.31219/OSF.IO/TM953.
} 
men is wider than for women. Also, access to ablution for men in several mosques in Banda Aceh is more effective because of the closer distance between the place of ablution and prayer when compared to the distance from the area of ablution to the location of prayer for women. The proximity of this access impacts the comfort of women in carrying out worship activities at the mosque. ${ }^{14}$ Greed $^{15}$ stated that in feminism, the biological differences between men and women should not bring about social constructs detrimental to women, including spatial use. Ahmad Gamal, as the head of the women-friendly prayer room renovation program at the Faculty of Engineering, University of Indonesia (FTUI) said the prayer room at the mosque they visited had problems with feasibility, holiness, and gender bias. ${ }^{16}$ The elements of visual privacy that are also a problem, such as entrances, windows, and walls, are often considered poorly planned so that there is a chance that the "aurat" (part of the body that to be covered according to Islam) will appear to nonmahram (is someone to whom she is not related, for instance, cousins, stranger, in-laws).

The research above shows that there has been no research that focuses on gender-responsive spatial planning in mosques. Therefore, this article is interesting to do. This research will look at whether the mosque as a public space is considered gender-friendly. By asking the question, are mosques in Banda Aceh gender friendly? A mosque is a public space that all people access, especially Muslims, men, women, and children. However, there are still many problems in spatial design and access to gender-discriminating facilities. The following are among some of the problems found in the field.

First, inadequate facilities such as; toilets for men and women, bathrooms, glass, bag hangers, slippers, air conditioning, dividers between male and female row, mukena (prayer hijab), carpets, and the Koran. Syarifah, ${ }^{17}$ an activist for women's empowerment at a public discussion about Madani city, said that she

\footnotetext{
${ }^{14}$ Observation.

${ }^{15}$ Greed, "Planning for Women and Other Disenabled Groups, with Reference to the Provision of Public Toilets in Britain."

${ }^{16}$ Admin UI Website, "Pengmas FTUI: Renovasi Ruang Ibadah Masjid Ramah Perempuan Universitas Indonesia," Universitas Indonesia, 2018, https://www.ui.ac.id/pengmas-ftui-renovasiruang-ibadah-masjid-ramah-perempuan/.

${ }^{17}$ In-depth interview on March 31, 2016.
} 
felt very uncomfortable with the layout and facilities of mosques and prayer rooms as a woman. "Women need a cooler room because, in addition to wearing clothes and headscarves, they also wear mukena. This causes the possibility of women feeling hot." Syarifah saw that air conditioning facilities were available sufficiently in the men's row/special room for men. Apart from that, Syarifah also criticized the ablution facility. It is not being made separately. The design of the ablution place sometimes does not consider the needs of women who move a lot, open the veil, and so on, including a place to hang bags and a mirror to improve wearing the hijab properly. Facilities that are not provided due to assumptions, for example, there is no place for ablution for women because women have already performed ablution from home. According to Musda, ${ }^{18}$ an academic at Ar-Raniry State Islamic University, Banda Aceh, a researcher on gender issues, said that it is difficult to find mosques that provide toilets for mosques outside urban areas places for wudhu specifically for women. "... it is difficult for us to find a place for ablution for women in village mosques, according to the mosque management because the women in the mosque have ablution at home". The data above shows that there are differences in the facilities provided for male and female congregations. Besides, the facilities that are not provided are affected by gender-biased assumptions.

Second, spatial planning is detrimental to one gender. For example, preliminary observations show that one of the mosques in the Pango, Banda Aceh, spatially setting the place of ablution for the male congregation is in front of the entrance of the female congregation, while the female congregation must make ablution at a farther location. In another case, there is a disproportionate division of space between men and women. The place for men's worship is wider than that of women; this is agreed by a female congregation "when I went to the mosque, I found a prayer place for women very narrow compared to the prayer room for male worshipers". ${ }^{19}$ Furthermore, the layout of the mosque space is more for certain genders because there is an understanding that one gender is considered needier than another gender. One example, libraries at the USK Language Institute only provide prayer rooms for female congregations and not for male congregations because there is an assumption

18In-depth interview on July 24, 2019.

${ }^{19}$ In-depth interview on March 9, 2020. 
that men are obliged to go to the mosque. Also, there is a policy at USK to prosper the Mosque (USK). The explanation above shows that differences in spatial arrangements are influenced by policymakers' assumptions and the habits of the people where there is a tendency to discriminate against one gender, both male and female.

Besides, the layout of the mosque which does not have the same standard occurs because the government did not intervene in spatial arrangements. According to available data, only Oman mosques have met the comfort standards for the congregation, this comes from the mosque manager's initiative. When this research was conducted, Fakhrudin, ${ }^{20}$ as the chairman of the Indonesian Mosque Council, said a drafting of a Governor Regulation on Standardization of Mosque Management by the Aceh Special Bureau. According to Fakhrudi, through this regulation, it is hoped that mosque managers will start to consider the concept of gender justice. Although according to him, this will be difficult to do especially since most of the mosques are owned by the community from self-help funds. Even so, this effort can be started from the government-owned mosque.

This paper refers to the Gender Planning theory introduced by Moser, gender planning seeks to emancipate women from subordinate positions and strive for equality, justice, and empowerment for women. ${ }^{21}$ This theory emphasizes the different roles between women and men in social life, resulting in different needs. The planner generally based planning policy on the western planning theory which consists of three basic assumptions that refer to the division of labor in the family. Firstly, the family includes the father, mother, and children. Secondly, the family's labor division focuses on the man being defined to have a productive role while the woman plays a reproductive worker. Thirdly, the family functions as a socio-economic unit wherein all adult members have equal access to resources and equal position in decision making concerning the family livelihood. However, this concept is not relevant with the position of women in the household as housewives having reproductive roles

${ }^{20}$ In-depth interview on March 10, 2020.

${ }^{21}$ Caroline Moser, Gender Planning and Development: Theory, Practice and Training (Routledge, 2012); Devaki Jain and Caroline O. N. Moser, "Gender Planning and Development: Theory, Practice and Training," Feminist Review, no. 49 (1995): 117, https://doi.org/10.2307/ 1395333. 
and are secondary income earners. The women's position is not equal to the men's because the latter plays roles such as being the breadwinner, productive worker, and family head.22

This research also uses three types of policy identification based on Naila Kabeer's ${ }^{23}$ gender planning: 1) gender-neutral, assuming that development is a gender-free activity, including the impact. City governments widely adopt this type of policy. 2) gender-sensitive, responding to different needs between men and women in specific development. This policy began to consider and design the layout of mosques in cities in the world. ${ }^{24}$ 3) Gender redistributive, carrying out gender transformation to balance relations between men and women in development.

This research uses a qualitative approach. Data collection in this study is sourced from primary data obtained from interviews with related parties and secondary data from documents, archives, journals, books, and legal products. This paper uses interview techniques with the in-depth interview method and observations. The study was conducted on mosques in Banda Aceh. Interviews were conducted formally and informally with several parties, namely women activists, the Indonesian mosque board, and the mosque congregation. The study was conducted to see how the mosques in Banda Aceh fulfill the concept of gender justice and gender planning to fulfill the principles of comfort for female visitors in carrying out worship.

\section{B. Mosque Facilities that do not Fit Responsive Gender}

This section will discuss three things related to mosque facilities that do not gender-responsive. First, inadequate facilities such as; toilets for men and women, bathrooms, glass, bag hangers, slippers, air conditioning, dividers between male and female row, mukena, carpets, and the Koran. Second, the facilities are not provided due to assumptions, for example, there is no place for wudu (ablution) for women because women have already performed

\footnotetext{
22Moser, Gender Planning and Development: Theory, Practice and Training.

${ }^{23}$ Naila Kabeer, Reversed Realities: Gender Hierarchies in Development Thought (London: Verso, 1994).

${ }^{24}$ Sandy Mahaputra, "Masjid Ramah Perempuan Bermunculan di Dunia," dream.co.id, 2014, https://www.dream.co.id/jejak/masjid-ramah-perempuan-mulai-bermunculan-di-seluruh-dunia141118h.html.
} 
ablution from home. Third, the mosque's public spaces cannot be accessed by everyone, for example, non-Muslims and women who do not wear clothes according to sharia.

\section{Inadequate Facilities}

At this point, we will discuss how inadequate facilities for male and female visitors have made mosque public spaces, not gender-responsive such as ablution places for men and women, bathrooms, mirrors, bag hangers, slippers, air conditioning, dividers between men's and women's row, mukena, carpets, and the Koran.

Finding a comfortable mosque for women is difficult, not only in the village but also in the city. Three students conveyed the inadequate mosque facilities from the Faculty of Economics, Universitas Syiah Kuala (USK). ${ }^{25}$ "Our prayer space is downstairs, and there is no air conditioning. We only use a fan, which is different from the prayer space for male congregations". Furthermore, according to Musda, an academic at UIN Ar Raniry and an activist on gender issues, this problem arose because men carried out development planning. Musda stated that "Women don't feel the need to be involved and leave it to men. Think men know their needs. Apart from that, women are too focused on certain needs which do not necessarily answer women's real needs. For example, village funds are allocated for community service equipment. Not for anything that has to do with comfort or access to anything ".26 Musda illustrates that the absence of women in planning causes the public space to be gender unresponsive. Apart from the problem of not being involved in making decisions for women in the development of public spaces. Women also have a tendency not to criticize or voice their need for a gender-responsive public space. It can be seen in research toilets specifically for women in coffee shops in Banda Aceh, where even though women have become part of coffee shops, women need to have separate toilets from men with several considerations including hygiene reasons, but no women have complained about this to the manager of the cafe for the women's only toilet that was not available. ${ }^{27}$

\footnotetext{
${ }^{25}$ Informal interview on July 24, 2019.

26In-depth interview on July 24, 2019.

27Fadlia, Darwin, and Ramadani, "Toilet Khusus Perempuan dan Warung Kopi di Banda Aceh (Sebuah Kajian terhadap Konsep Keadilan Gender dan Gender Planning).”
} 
Facilities that are not available and adequate for female congregations greatly disturb the comfort of worship. For example, air conditioners or fans are available in the male row but not available in the female row. Meanwhile, women's need for this facility is greater than men's because women wear a mukena which causes them to feel hot faster. This was conveyed by Syarifah, that there is a need for women to get the same or more facilities than men, but these facilities are not available. "Women need wider toilets and ablution places because women need more space to move, we also need a place to hang bags, mirrors. In the place of prayer, women also need air conditioning, because we wear clothes and prayer clothes, so it's easier to feel hot." Syarifah is a woman who is quite affirmative in conveying the needs of women, the statement above was conveyed when she was one of the participants in the Focus Group Discussion which discussed the Concept of the Banda Aceh Civil City. According to Syarifah, the concept of Madani City also includes considering the needs and comfort of women in designing public facilities. ${ }^{28}$ The explanation above illustrates how unavailable and inadequate facilities can cause inconvenience for one gender.

\section{Facilities that are not Provided Due to Gender Values in the Community}

This section discusses how the value of gender in society on the presence of gender of men and women in the public space impacts the facilities provided or not provided. In a study conducted by Mona Domosh and Joni Seager, since the 1500th-century public space has been described as "masculine" and women are not part of the public sphere. "The public arena has been described as masculine since the 1500th century. During this time women's access to the public was strictly limited and they were mostly banished to the home."29 The layout facilities of the mosque, an example of this assumption, can be seen in the absence of ablution places for women in some mosques, especially in villages

\footnotetext{
${ }^{28}$ Admin, "FISIP UIN Ar-Raniry Siap Dukung Banda Aceh Menuju Kota Madani," bandaacehkota.go.id, 2016, https://bandaacehkota.go.id/berita/5962/fisip-uin-ar-raniry-siapdukung-banda-aceh-menuju-kota-madani-2.html.

${ }^{29}$ Mona Domosh and Joni Seager, Putting Women in Place: Feminist Geographers Make Sense of the World (New York: Guilford Press, 2001); Susan M. Walcott, "Putting Women in Place: Feminist Geographers Make Sense of the World. Mona Domosh and Joni Seager; The Twenty-First Century City: Resurrecting Urban America. Mayor Stephen Goldsmith," Urban Geography 24, no. 3 (May 16, 2003): 272-272, https://doi.org/10.2747/0272-3638.24.3.272.
} 
because of the gender assumption that women do not pray in mosques or mosques women have prayed. ablution from home or even pray at home. Research conducted by Hayati ${ }^{30}$ concluded that the male doctrine emphasizes that men are the gender who work outside the home and use public facilities and spaces, while women are the gender who work in the domestic space, it also means that women are not present in public spaces and access public facilities causing urban spatial planning not reserved for women. Musda said that if she travels out of town and has to pray while traveling, she usually finds mosques in rural areas not providing toilets and ablution facilities for women, even if a toilet is provided for women, it is usually dirty and poorly maintained. According to Musda, this happened because of the assumption that women prayed or had performed ablution at home. However, the traveling conditions she experienced disturbed his comfort when she was going to worship. ${ }^{31}$

Gender values in society that also influence the layout and facilities of mosques are the recommendation for women to pray at home. It was also agreed upon by the management of the Oman mosque, Lampriet, Banda Aceh. However, this mosque is included in the category that is friendly to women. According to the management, ${ }^{32}$ there is no difference in facilities for men and women at this mosque. It disproves the provisional assumption from the preliminary data of this study that Omani mosques use a gender-friendly perspective on the design of buildings and facilities. This study found that Omani mosques apply a gender-neutral concept, where there is no difference between male and female facilities. The following is the statement of one of the mosque administrators, "We do not differentiate between facilities for male and female congregations, if what we have done turns out to be comfortable for the congregation, this is certainly good news for us." 33 The explanation above can provide an overview of how assumptions can affect the layout and facilities in mosque public spaces. Assumptions that affect the layout and facilities of mosques are detrimental to one gender group in accessing mosque public spaces.

\footnotetext{
${ }^{30}$ Hidayati, "Feminisme dan Tata Ruang Kota."

31In-depth interview on July 24, 2019.

${ }^{32}$ In-depth interview with Management of Oman Mosque Banda Aceh on July 26, 2019.

33In-depth interview with Management of Oman Mosque Banda Aceh on July 26, 2019
} 


\section{E. Spatial Arrangements that are Detrimental to One Gender Group}

This section will discuss how the layout of the mosque prioritizes and harms one gender, in this case, the gender of women is more disadvantaged in terms of easy access to space. The study found three things that can illustrate how women's gender is disadvantaged by spatial planning. First, the distance between the toilet/place of ablution and the entry point for the women's congregation is too long. Second, when there is a development or expansion of women's congregations, they are often disadvantaged by being placed in the basement or terrace. Third, there are no directions for ablution places and toilets. If men and prayer places are close together, for female congregations, it tends to be far away.

Some mosques tend to place ablution places for women and women's toilets far from the entrance and prayer places, this makes it difficult for women because they have to remove their socks, headscarves, gloves. One student of the Universitas Syiah Kuala (USK) stated:

"I have the experience of praying at the Baitul Mukminin mosque, Pango. When I wanted to take ablution water, I thought the place to take women's ablution was right in front of the entrance. It turned out that it was for men and the place for wudu for women was at the back, which is a bit far from the mosque. It was very troublesome for me because I had to take off my socks, take off and put on my hijab, and there were no sandals available. It is very different from the Omani mosque where the place of ablution is connected to the prayer room so that women do not need to open and put on socks and headscarves." 34

It turns out that the place of ablution is far from the place of prayer (not connected) is also felt by the male gender, where he feels uncomfortable with the mosque where the ablution place is far from the place of prayer. A student of UIN Ar Raniry, ${ }^{35}$ said, "I'm not comfortable if the ablution place is not connected to the prayer room, because after purifying I met women who were not mahram", he also said that the Oman mosque was friendly and made him feel comfortable.

The arrangement of the mosque's layout when there is construction or pension often disadvantages female congregations by being placed in the lower room or terrace. One student of $\mathrm{USK}^{36}$ gave an example when she was going to

\footnotetext{
${ }^{34}$ Interview with interview with Universitas Syiah Kuala Students on July 25, 2019.

35Interview with interview with UIN Ar-Raniry Students on July 24, 2019.

36Interview with Universitas Syiah Kuala students on July 25, 2019.
} 
pray at the campus mosque of the Faculty of Economics, USK. She found a place for women's prayer on the mosque's terrace, and for her, this situation made her feel uncomfortable because there were no walls made to keep wind and rain away. It continued throughout the repair and construction of the mosque. Female congregation placed on basement when the campus mosque renovated, 37 This caused one of the female congregations to feel uncomfortable praying because it was stuffy and humid. Apart from the hot weather, this place of prayer became hotter with inadequate air conditioning facilities.

In general, the layout of the mosque places the place of ablution for men close to the place of prayer, and this is easily seen from the entrance of the mosque so that most male congregations are not confused about finding a place for ablution, this is different from what female congregations feel. When they enter the mosque, it is difficult to know where the toilet is and where the ablution is. It is because there is no standard of layout for the mosque regarding the placement of ablution places. When she visited one of the mosques in the Lamdingin area, this was felt by a female congregation because the ablution place is on the left, far from the place for women's prayer. Even at that time, she had to go around the mosque to find a place for ablution. Another experience was conveyed by one of the congregation, ${ }^{38}$ "When I entered the Ulee Lheue mosque, it was difficult for me to find a toilet and a place for women's ablution, I had been looking around and found the toilet in the right rear wing, near where the male entrance. I also experienced this when visiting several mosques in Banda Aceh.

The problem of directions not available in mosques and spatial layouts that do not have the same standard does not occur in prayer rooms at gas stations that are more easily accessible for mushalla users. This was conveyed by interviews with three students from the Faculty of Economics USK. ${ }^{39}$ They prefer to pray at petrol stations because of the clear signs and separation between the toilets and the ablution places for men and women. "When I travel, I am more comfortable praying at a prayer room at a gas station. Usually cleaner, easier to find, a place for ablution which is connected to a place of

\footnotetext{
37Interview with Universitas Syiah Kuala students on July 25, 2019.

38Interview with the congregation on July 24, 2019.

${ }^{39}$ Interview with Universitas Syiah Kuala students on July 25, 2019.
} 
prayer". According to them, the layout and model of a prayer room at the same gas station in all places make it easier for visitors to access the mosque.

The explanation above illustrates how spatial arrangements can harm one or both gender groups through the long distance between the toilet/place of ablution and the entry point for women's congregations, placing women's congregations in places that are not strategic when there is development or expansion. There is no direction where the ablution and toilets are located.

Here are some photos showing the layout of the Oman Al-Makmur mosque in Banda Aceh which is gender-neutral and women-friendly. The pictures show parts of the Oman mosque facilities that are made equal between men and women or are called gender-neutral, even though this mosque is a mosque that is considered women-friendly for visitors or female worshipers

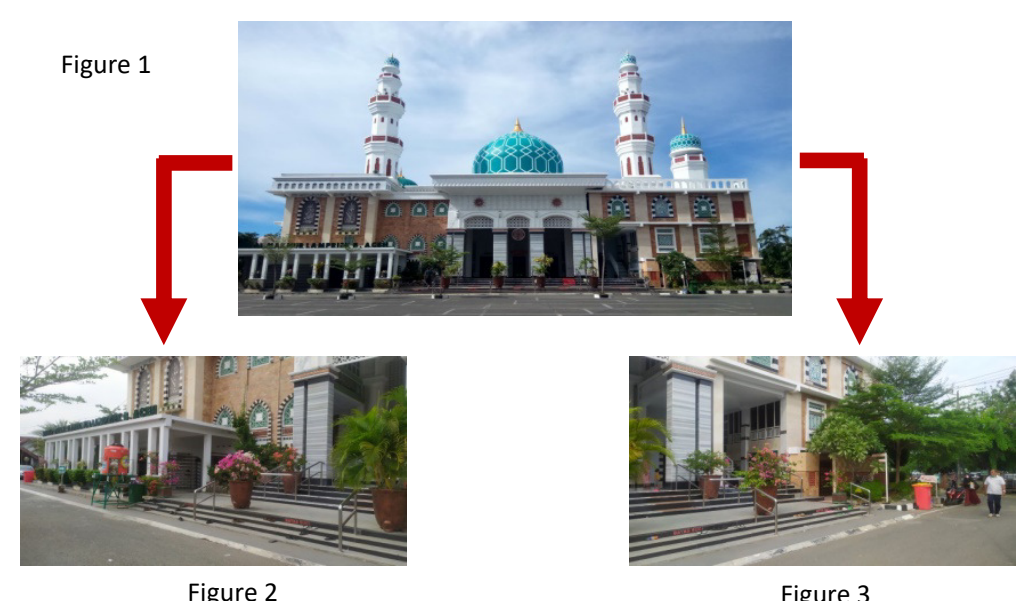

Figure 1. Oman mosque from the front with toilets and ablution for men and women on both sides. Figure 2. A place for ablution and a men's toilet with a direct path on the inside leading to the prayer room. Figure 3. A place for ablution and a women's toilet with a direct path on the inside leading to the prayer room. 
Women Friendly Mosque in Banda Aceh ....

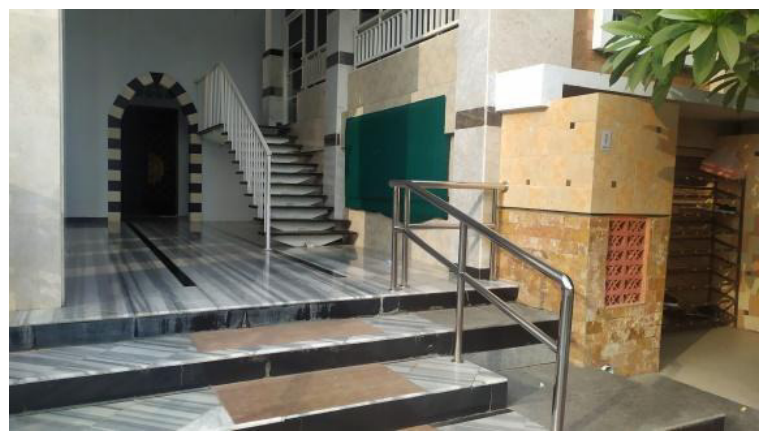

Figure 4.

The entrance to the prayer room for men and women without passing through the place of ablution.

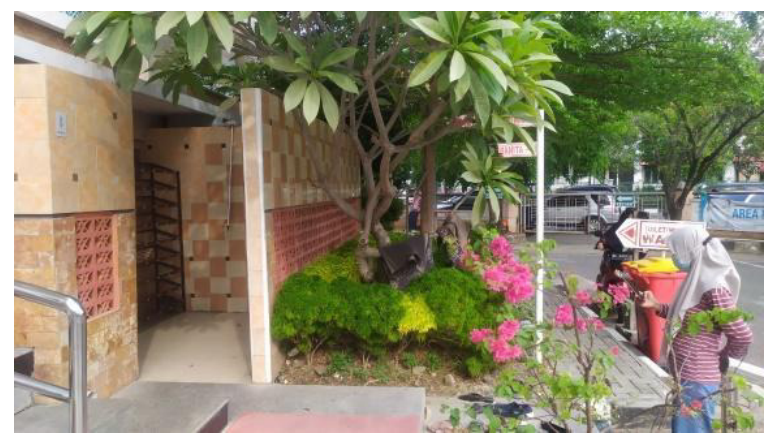

Figure 5.

Toilets and places for women's ablution from door 1 (one).

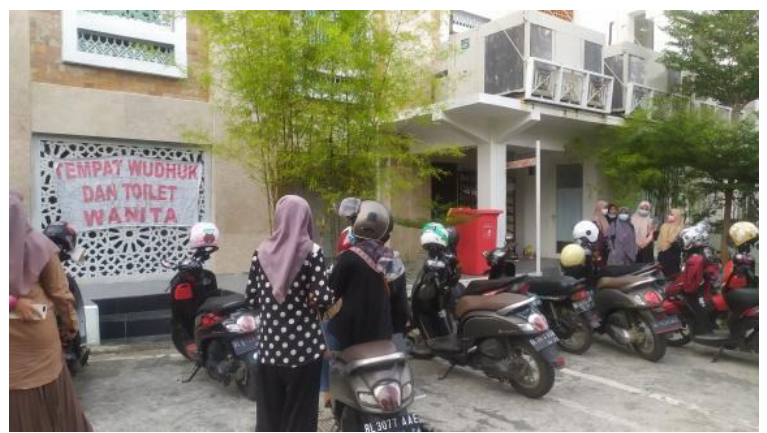

Figure 6.

Toilets and places for women's ablution from door 2 (two). 
Faradilla Fadlia, Ismar Ramadani, Siti Nur Zalikha

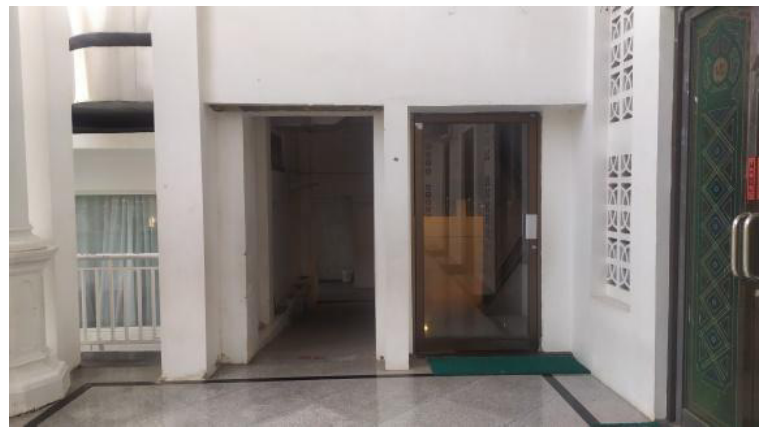

Figure 7.

The entrance that is connected to the toilet and the place for women's ablution leads to the women's prayer room.

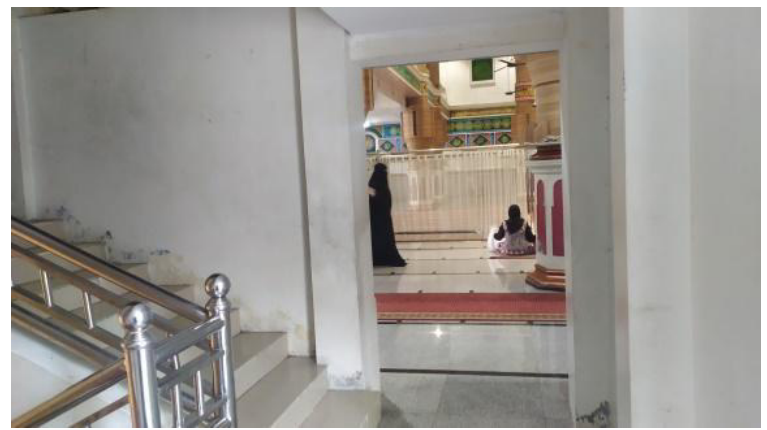

Figure 8.

The entrance that is connected to the toilet and the place for women's ablution leads to the women's prayer room.

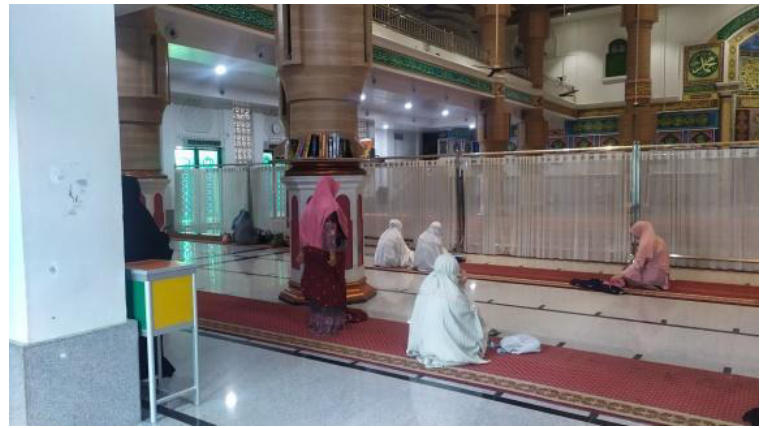

Figure 9.

Women's prayer room. 


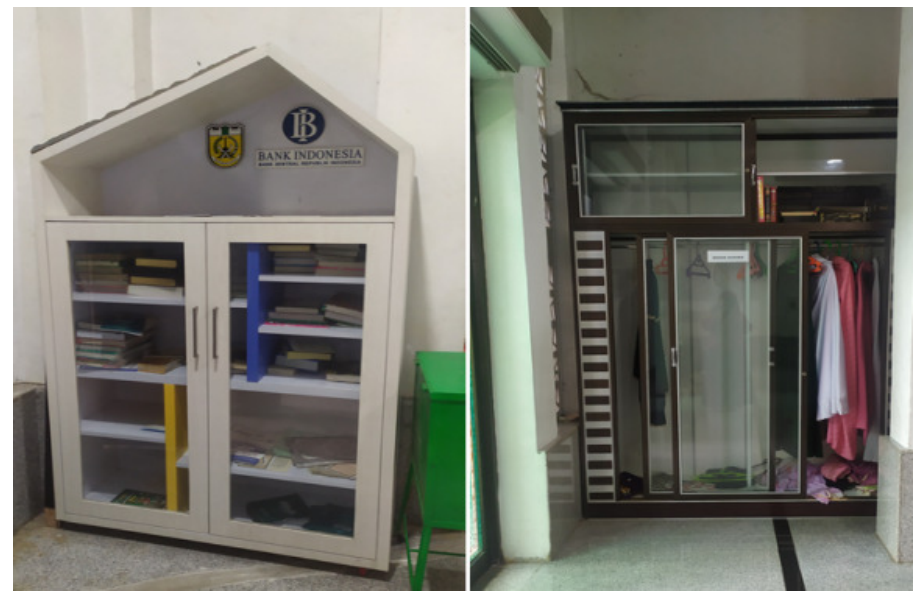

Figure 10.

Al-Qur'an and Mukena in the women's prayer room.

\section{F. Conclusion}

Based on the discussion above, In general, mosques in Banda Aceh are not yet gendered responsive. It can be seen from several findings in this study. First, mosque facilities are not gender-responsive, where there are inadequate facilities for male and female visitors, which causes the mosque's public space to be gender unresponsive. Some of these facilities include ablution places for men and women, bathrooms, mirrors, bag hangers, slippers, air conditioning, dividers between men's and women's row, mukena's, carpets, and the Koran.) Also, this study also found that the facilities were not provided because of the assumption, for example, there was no place for wudu for women because the assumption was that women had already performed ablution from home. Second, spatial arrangements are detrimental to one gender group: The study found three things that can illustrate how women's gender is disadvantaged by spatial planning. First, the distance between the toilet/place of ablution and the entry point for the women's congregation is too long. Second, when there is construction or expansion of mosques, female congregations are more often disadvantaged because prayer places for women are usually placed in basements or terraces. Third, there are no directions for ablution places and toilets. 
If men and prayer places are close together, for female preyer it tends to be far away.

This study concludes with four things from the above findings and based on the concept of gender planning in public spatial planning policies. A temporary conclusion that Oman mosques are considered gender-responsive is in the gender-neutral category. Second, the comfort and inconvenience related to spatial planning and facilities are experienced by female congregations and male congregations. Third, assumptions that affect spatial planning and facilities discriminate against one gender group. Fourth, mosques in Aceh are generally intended for men, this has resulted in the mosque layout not accommodating women's needs.[s]

\section{References}

Admin. "FISIP UIN Ar-Raniry Siap Dukung Banda Aceh Menuju Kota Madani." bandaacehkota.go.id, 2016. https://bandaacehkota.go.id/berita/5962/fisip-uinar-raniry-siap-dukung-banda-aceh-menuju-kota-madani-2.html.

Admin UI Website. "Pengmas FTUI: Renovasi Ruang Ibadah Masjid Ramah Perempuan Universitas Indonesia." Universitas Indonesia, 2018. https://www. ui.ac.id/pengmas-ftui-renovasi-ruang-ibadah-masjid-ramah-perempuan/.

Amalia, Andi Nurfajrina. "Memahami Karateristik Perempuan di Masjid." OSF Preprint, 2020. https://doi.org/10.31219/OSF.IO/TM953.

Bondi, Liz. "Gender, Class, and Urban Space: Public and Private Space in Contemporary Urban Landscapes." Urban Geography 19, no. 2 (1998): 160-85. https://doi.org/ 10.2747/0272-3638.19.2.160.

Chelkoff, Grégoire, and Jean-Paul Thibaud. "L'espace Public, Modes Sensibles: Le Regard Sur La Ville." In Les Annales de La Recherche Urbaine, 7-16, 1992.

Domosh, Mona, and Joni Seager. Putting Women in Place: Feminist Geographers Make Sense of the World. New York: Guilford Press, 2001.

Fadlia, Faradilla, Rizkika Lhena Darwin, and Ismar Ramadani. "Toilet Khusus Perempuan dan Warung Kopi di Banda Aceh (Sebuah Kajian terhadap Konsep Keadilan Gender dan Gender Planning)." Gender Equality: International Journal of Child and Gender Studies 2, no. 1 (2016): 11-22. https://doi.org/ 10.22373/equality.v2i1.1449.

Francis, Mark. "Control as a Dimension of Public-Space Quality." In Public Places and Spaces, 147-72. Springer, 1989. 
Franck, Karen A, and Lynn Paxson. "Women and Urban Public Space." In Public Places and Spaces - Human Behavior and Environment, 121-46. Springer, 1989.

Gorman-Murray, Andrew, and Peter Hopkins. Masculinities and Place. Oxfordshire: Routledge, Taylor \& Francis Group, 2018.

Greed, Clara H. "Planning for Women and Other Disenabled Groups, with Reference to the Provision of Public Toilets in Britain." Environment and Planning A: Economy and Space 28, no. 3 (1996): 573-88. https://doi.org/10.1068/a280573.

Hayden, Dolores. "What Would a Non-Sexist City Be like? Speculations on Housing, Urban Design, and Human Work." Signs: Journal of Women in Culture and Society 5, no. S3 (1980): S170-87.

Hidayati, Isti. "Feminisme dan Tata Ruang Kota." Research Works and Publications in Urban and Regional Planing Universitas Gadjah Mada, 2015. https://pwk. archiplan.ugm.ac.id/publication/.

Jain, Devaki, and Caroline O. N. Moser. "Gender Planning and Development: Theory, Practice and Training." Feminist Review, no. 49 (1995): 117. https://doi.org/ 10.2307/1395333.

Kabeer, Naila. Reversed Realities: Gender Hierarchies in Development Thought. London: Verso, 1994.

Lucio, Ramón López de. “El Espacio Público En La Ciudad Europea: Entre La Crisis y Las Iniciativas de Recuperación. Implicaciones Para Latinoamérica Revista de Occidente, 230-231, 2000." Revista de Occidente 230-231 (2000): 105-21.

Mahaputra, Sandy. "Masjid Ramah Perempuan Bermunculan di Dunia." dream.co.id, 2014. https://www.dream.co.id/jejak/masjid-ramah-perempuan-mulaibermunculan-di-seluruh-dunia-141118h.html.

McDowell, Linda. Género, Identidad y Lugar: Un Estudio de Las Geografías Feministas. Vol. 60. València: Universitat de València, 2000.

Moser, Caroline. Gender Planning and Development: Theory, Practice and Training. Routledge, 2012.

Muxi, Jordi Borja Zaida. L'espai Públic: Ciutat i Ciutadania. Barcelona: Diputació de Barcelona, Àrea de Cooperació, Oficina Tècnica de Cooperació, 2001.

Sandercock, Leonie, and Ann Forsyth. "A Gender Agenda: New Directions for Planning Theory." Journal of the American Planning Association 58, no. 1 (1992): 49-59. https://doi.org/10.1080/01944369208975534.

Valle, Teresa Del. Andamios Para Una Nueva Ciudad: Lecturas Desde La Antropología. Vol. 39. València: Universitat de València, 1997.

Walcott, Susan M. "Putting Women in Place: Feminist Geographers Make Sense of the World. Mona Domosh and Joni Seager; The Twenty-First Century City: 
Faradilla Fadlia, Ismar Ramadani, Siti Nur Zalikha

Resurrecting Urban America. Mayor Stephen Goldsmith." Urban Geography 24, no. 3 (May 16, 2003): 272-272. https://doi.org/10.2747/0272-3638.24.3.272.

Walzer, Michael. "Public Space-Pleasures and Costs of Urbanity." Dissent 33, no. 4 (1986): 470-75.

Wekerle, Gerda R. "A Woman's Place Is in the City." Antipode 17, no. 2-3 (1985): 14553. 